\section{Variation in Reproductive Characteristics and Seed Production in the USDA Garlic Germplasm Collection}

\author{
Maria M. Jenderek \\ U.S. Department of Agriculture, Agricultural Research Service, National Arid \\ Land Plant Genetic Resource Unit, 9611 S. Riverbend, Parlier, CA 93648
}

Richard M. Hannan

U.S. Department of Agriculture, Agricultural Research Service, Western

Regional Plant Introduction Station, 59 Johnson Hall, Pullman, WA 99164

Additional index words. Allium sativum, Allium longicuspis, true seeds, in vitro pollen germination, bulbils, flower anomalies

Abstract. Diverse garlic germplasm has proven to be essential for production of true seed. Yet, fertile accessions in garlic germplasm collections have not been characterized for breeders and researchers, and information on morphological characteristics associated with seed producing plants is very limited. The objective of this study was to evaluate reproductive characteristics and true seed production capacity in the USDA garlic germplasm collection. Most stable traits, such as flower stem appearance, opening ability of spathe, level of difficulty to remove bulbils, tepal color, umbel shape, and the number of flowers per umbel, were similar across populations evaluated. Other characteristics including position of stigma, tepal closure, pollen viability, time of flowering, scape senescence rate, and number of seeds produced by individual plants varied within accession evaluated. Of 47 accessions, 19 produced true seeds (from 48.5 to 1.5 seeds per plant) in the Central Valley of California. Seed production in the germplasm evaluated is adequate to initiate garlic breeding projects.

True seed development in garlic (Allium sativum L. and A. longicuspis Regel) has been reported in literature for almost 50 years (Kononkow, 1953). In the past 18 years, several reports on the production of large numbers of seed were published (Etoh, 1986; Etoh et al., 1988; Inaba et al., 1995; Jenderek, 1998; Jenderek and Hannan, 2000; Konvicka, 1984; Pooler and Simon, 1994). In spite of this, seedproducing germplasm is not readily available for garlic breeders and seed producers. Fertile germplasm is of great interest not only to breeders, but also to small farm garlic producers interested in developing novel products for niche markets. Garlic florogenesis was described by Hua et al. (1994) and Kamenetsky and Rabinowitch (2001), but comprehensive description of flower traits and seed production ability is very limited.

The USDA National Plant Germplasm System garlic collection is maintained at the Western Regional Plant Introduction Station (WRIPS), Pullman, Wash. Currently, 195 accessions of A. sativum and 10 accessions of A. longicuspis from 27 countries are available for research. A preliminary evaluation of seed production ability of selected accessions in this collection was reported by Jenderek and Hannan (2000), but the variation in flowering and fertility was not described. The objective of this study was to evaluate garlic clones selected from the NPGS collection for seed producing ability, and to identify characteristics that were associated with reproductive capacity.

Received for publication 16 Dec. 2002. Accepted for publication 30 Sept. 2003

HortScience Vol. 39(3) June 2004 ease of bulbil removal, number of bulbil removal, number of umbel, umbel shape, time of flowering, tepal and bulbil appearance, anther color (at full anthesis), pollen viability, scape senesce rate, and the number of seeds.

Pollen germination tests were conducted in vitro, on $1 \%$ water agar containing $15 \%$ sucrose. After $\approx 20 \mathrm{~h}$ of incubation at room temperature, slides were stained with lacmoid/ martius yellow dye ( $\mathrm{pH} 8.0)$. The number of stainable pollen grains (stained green-purple), and the number of germinated grains (with tubes) were counted under a compound microscope $(100 \times)$. For each accession, pollen grains from two anthers of five flowers were evaluated. Data on stainable and germinated pollen were analyzed by one way ANOVA, using Duncan's new multiple range for mean separation at $1 \%$ level (SPSS, 2001).

\section{Results and Discussion}

Of 47 garlic clones evaluated, plants of 17 accessions developed a strong scape (round in shape, 5 to $7 \mathrm{~mm}$ in diameter), 10 clones had a weak scape (with an oval or flattened cross section, 1 to $3 \mathrm{~mm}$ ), 18 accessions senesced and were harvested before flower stalk extended over the youngest leaf, and 2 accessions (PI 250662 and W6 2560) did not bolt at all (Table 2 ). In the 10 accessions with a weak scape, the stalk grew slightly over the youngest leaves and senesced shortly after, similar to the incomplete bolting clones described by Takagi (1990). In bolting garlic types, the presence of plants without a fully developed flower stalk (scape) or any stalk is not uncommon (Kazakova, 1971; Pooler and Simon, 1993). In addition to genetic factors, the initiation of a flower stalk in garlic is influenced by environmental factors (Mann, 1952, 1958; Pooler and Simon, 1993; Takagi, 1990), and the size of planting material. In this study, only plants derived from bulbs with a strong scape produced seeds. The height of flower stalks, measured from the soil level to the top of the inflorescence, varied from 45 to $121 \mathrm{~cm}$ and was not related to seed producing ability of the accessions evaluated (Tables 2 and 3). However, large differences in the flower stalk height may present difficulties in potential crosses of specific breeding lines. Flower stalks longer than $70 \mathrm{~cm}$ had a tendency to bend, and in some instances, required a physical support to prevent lodging.

Among seed producing accessions, the spathe on plants of four accessions did not open in early stages of flower bud development (PI 493099, PI 515972, PI 540316, and PI 540327) so the spathe was mechanically opened to enable flower development and bulbil removal. In plants of the four accessions grown in a separate plot, the spathe opened 2 to 3 weeks after stalks were fully extended, but the flower buds were already overgrown by bulbils. A spathe opening naturally early in umbel development eliminated the need for spathe removal, and therefore, such clones were more suitable for seed production.

All plants evaluated developed bulbils in inflorescences. The bulbils were removed mechanically to enable flower development. Three accessions were ranked into an easy bulbil removal group (PI 491116, PI 540319, 
and PI 540337), and five accessions were classified as intermediate. All others were rated as difficult bulbil removal. Plants of PI 540319 and W6 1861 developed typical flowers without bulbil removal, but they did not develop seeds 540319 shed easily when flower stalks were shaken by hand. The shedding characteristic substantially lowered the time needed for bulbil removal. The color, size and number of bulbils varied across the accessions evaluated, but were uniform within each accession. Small bulbils (5.0 to $5.8 \mathrm{~mm}$ long and 2.0 to $2.6 \mathrm{~mm}$ wide) were usually white or purple white. With maturity, upper tips of the white bulbils turned slight purple or brown. Medium size and large size (11.1 to $15.8 \mathrm{~mm}$ long and 7.1 to $16 \mathrm{~mm}$ wide) bulbils were either brown or shades of purple (Table 3 ). Different color intensities among bulbils within an umbel and between umbels of the same accession were observed. The color of the bulbils was often in separate plots. Bulbils on the plants of PI (6.6 to $9.5 \mathrm{~mm}$ long and 4.5 to $7.8 \mathrm{~mm}$ wide)

similar to the color of the clove and outer bulb skin, with some difference in color intensity. In preliminary observations of selected plants, the number of bulbils that developed before first bulbil removal was similar to the number of flowers present in the umbel. At each subsequent bulbil removal, the number of bulbils was lower than previously, but proportional to the flower number in the umbel.

In 1999, plants began to bloom on June 10 (PI 493099 and PI 540319), and the last accessions flowered on July 30 (PI 540316 and PI 540327, Table 3). The time of garlic flowering varied from year to year. For the 10 accessions evaluated over 3 years, the earliest observed bloom occurred in the last week of May (25 May 2000, PI 540319) and the latest bloom was observed at the beginning of August (3 Aug. 2000, PI 540356). For a given clone, plants usually bloomed over 25 to $50 \mathrm{~d}$. The number of flowers/umbel was evaluated using the following scale: $1=\leq 10,2=11$ to 50,3 $=51$ to $100,4=101$ to 200 , and $5=>200$.

Table 1. Garlic accessions from 18 countries evaluated for flowering and seed production in the Central Valley of California.

\begin{tabular}{|c|c|c|c|}
\hline Accession & Species & Origin & $\begin{array}{l}\text { Year introduced to } \\
\text { the USDA collection }\end{array}$ \\
\hline PI 250662 & Allium sativum & USSR & 1958 \\
\hline PI 470923 & Allium sativum & Philippines & 1982 \\
\hline PI 493105 & Allium sativum & Turkey & 1984 \\
\hline PI 493116 & Allium sativum & Czechoslovakia & 1984 \\
\hline PI 497951 & Allium sativum & Syria & 1985 \\
\hline PI 515972 & Allium sativum & U.S., Washington & 1988 \\
\hline PI 540316 & Allium sativum & USSR & 1985 \\
\hline PI 540318 & Allium sativum & Pakistan & 1988 \\
\hline PI 540319 & Allium sativum & USSR & 1988 \\
\hline PI 540321 & Allium sativum & Syria & 1988 \\
\hline PI 540327 & Allium sativum & Brazil & 1986 \\
\hline PI 540328 & Allium sativum & Brazil & 1986 \\
\hline PI 540335 & Allium sativum & Czechoslovakia & 1986 \\
\hline PI 540337 & Allium sativum & Czechoslovakia & 1986 \\
\hline PI 540340 & Allium sativum & Czechoslovakia & 1986 \\
\hline PI 540346 & Allium sativum & Germany & 1986 \\
\hline PI 540349 & Allium sativum & Germany & 1986 \\
\hline PI 540356 & Allium sativum & Georgia & 1985 \\
\hline PI 540360 & Allium sativum & U.S., Washington & 1985 \\
\hline PI 540362 & Allium sativum & U.S., Iowa & 1985 \\
\hline PI 540371 & Allium sativum & U.S., Illinois & 1985 \\
\hline PI 543049 & Allium sativum & Pakistan & 1988 \\
\hline W6 670 & Allium sativum & Turkey & 1989 \\
\hline W6 1860 & Allium sativum & Turkmenistan & 1989 \\
\hline W6 1861 & Allium sativum & Uzbekistan & 1989 \\
\hline W6 1862 & Allium sativum & Uzbekistan & 1989 \\
\hline W6 1883 & Allium sativum & Uzbekistan & 1989 \\
\hline W6 1885 & Allium sativum & Uzbekistan & 1989 \\
\hline W6 1890 & Allium sativum & Uzbekistan & 1989 \\
\hline W6 2558 & Allium sativum & USSR & 1989 \\
\hline W6 2560 & Allium sativum & Greece & 1989 \\
\hline W6 4462 & Allium sativum & China & 1990 \\
\hline W6 4464 & Allium sativum & China & 1990 \\
\hline W6 10472 & Allium sativum & Syria & 1992 \\
\hline W6 10473 & Allium sativum & Egypt & 1992 \\
\hline W6 10734 & Allium sativum & Bulgaria & 1992 \\
\hline W6 10738 & Allium sativum & Bulgaria & 1992 \\
\hline W6 10739 & Allium sativum & Bulgaria & 1992 \\
\hline W6 12825 & Allium sativum & Germany & 1990 \\
\hline W6 12911 & Allium sativum & Korea & 1993 \\
\hline W6 17260 & Allium sativum & China & 1995 \\
\hline W6 17281 & Allium sativum & Turkmenistan & 1995 \\
\hline PI 493099 & Allium longicuspis & USSR, Moldavia & 1984 \\
\hline PI 540314 & Allium longicuspis & USSR & 1985 \\
\hline PI540315 & Allium longicuspis & USSR & 1985 \\
\hline PI 540357 & Allium longicuspis & USSR & 1985 \\
\hline W6 12820 & Allium longicuspis & U.S., Illinois & 1990 \\
\hline
\end{tabular}

The largest number of flowers observed was slightly over 300 (309 flowers, PI 540319, in all 3 years). The top seed producers in 1999 (PI 540314, PI 493116, and PI 493099, Table 2) had over 100 flowers per umbel, but none of them produced seed in all flowers. Since each flower has a potential of producing 6 seeds, in an ideal situation each inflorescence of those accessions could produce at least 600 seeds. However, such a high level of seed production was never observed. Based on appearance, the umbel shape was classified as either round umbel or flat umbel (Harris and Woolf Harris, 1994). The shape of the umbel was associated with the number of flowers developed. In flat umbels (PI 515972, PI 540349, W6 1890, W6 2558 , and W6 12825, Table 3 ) the number of flowers was usually below 100 (up to 60 flowers), with stiffer pedicels than in round umbels which usually had $>100$ flowers.

The most common tepal color was purple or light purple, with or without darker veins, and with or without darker tips. In most flowers, tepal attitude was open, however in two accessions (PI 540319 and W6 1861) beside open tepal flowers, flowers with 'closed' tepals were observed (Table 3 ). In open flowers, the tepals were positioned at less than a $45^{\circ}$ angle to the style. Whereas, in closed flowers the tepal was adjacent to the style. The height of the stigma in plants with closed flowers was either above, or slightly below the tepal tips. This study suggested that garlic flowers exhibited heterostyly within the two clones $(\approx 20 \%$ to $30 \%$ of plants). However, more observations are needed to determine if this characteristic is stable across the species.

Most anthers with fertile pollen were purple, except in PI 540340, which had yellow anthers. Within 5 accessions (PI 493116, PI 540314, PI 540337, W6 1861, and W6 1890) with predominantly purple anthers, $20 \%$ to $30 \%$ of plants had yellow anthers (Table 3). Male fertility was usually associated with purple colored anthers (Etoh, 1983; Konvicka, 1984). However, yellow anthers with viable pollen, were also observed previously (Jenderek and Hannan, 2000; Pooler and Simon, 1994). Yellow anthers without viable pollen grains usually shriveled shortly after anthesis, before their pollen grains were released. The highest percentage of viable (stainable) pollen was observed in plants of W6 $1885(97.8 \%)$, however the pollen viability of 5 other accessions (PI 540319, PI 540335, PI 540337, PI 540356, and W6 1861) was statistically similar to W6 1885 (Table 3). Pollen tube development was highest in pollen from PI 540340 (27.3\%); statistically similar level of pollen tubes was observed in PI 540335. Filament length varied between plants not only among the accessions, but also within plants of the same accession. In closed flowers with short filaments only tips of anthers protruded and no pollen was visible outside the flowers. This may influence the pollen availability to pollination vectors.

Leaves in garlic senesce rapidly, following full bloom. At this point, some flower stalks began to senesce too. Chlorosis started at the base of the flower stalk and progressed upwards to the umbel. Konvicka (1984) described this 
process as a typical phenomenon occurring in the genus Allium. The onset of chlorosis due to senescence varied across and within the accessions and was described as slow, intermediate and rapid (Table 3). Stalks with slow chlorophyll degradation remained green or light green until bloom of all flowers in the umbel was completed, where stalks with rapid senescence lost their green color before anthesis of first flowers in the umbel. Eventually all stalks senesce, and plants with the most rapid chlorophyll degradation did not produce seeds. One possible reason for lack of true seed development on those plants may be due to a shortage of nutrients provided by the scape.

Umbels exhibited a wide variation of flower anomalies. Presence of numerous leaf bracts on the peripheries of an umbel or in the whole inflorescence was frequently noted. In several

Table 2. Number of seeds and scape appearance in bulbs of garlic accessions.

\begin{tabular}{|c|c|c|c|c|c|}
\hline \multirow[b]{3}{*}{ Accession } & \multicolumn{2}{|c|}{$\begin{array}{l}\text { Appearance of } \\
\text { scape in bulbs }{ }^{2}\end{array}$} & & & \\
\hline & \multirow{2}{*}{$\begin{array}{l}\text { Before planting } \\
\text { (as received from } \\
\text { Pullman, Wash.) }\end{array}$} & \multirow{2}{*}{$\begin{array}{c}\text { After harvest } \\
\text { (Parlier, Calif.) }\end{array}$} & \multicolumn{3}{|c|}{ Seeds /plant (no.) } \\
\hline & & & 1999 & 2000 & 2001 \\
\hline$\overline{\text { PI } 540314}$ & $\mathrm{sg}$ & $\mathrm{sg}$ & 48.5 & 8.0 & 5.5 \\
\hline PI 493116 & $\mathrm{sg}$ & $\mathrm{sg}$ & 15.4 & 3.4 & 1.6 \\
\hline PI 493099 & $\mathrm{sg}$ & $\mathrm{sg}$ & 12.5 & & \\
\hline PI 540337 & $\mathrm{sg}$ & $\mathrm{sg}$ & 11.7 & & \\
\hline PI 540356 & $\mathrm{sg}$ & sg & 9.7 & 0.7 & 5.2 \\
\hline PI 540319 & $\mathrm{sg}$ & sg & 9.5 & 14.3 & 7.0 \\
\hline PI 540357 & sg & sg & 9.1 & 1.0 & 10.0 \\
\hline PI 540340 & $\mathrm{sg}$ & $\mathrm{sg}$ & 8.3 & & \\
\hline PI 540316 & $\mathrm{sg}$ & $\mathrm{sg}$ & 7.8 & & \\
\hline PI 540335 & $\mathrm{sg}$ & $\mathrm{sg}$ & 7.8 & & \\
\hline PI 540327 & sg & wk & 5.0 & & \\
\hline W6 1885 & $\mathrm{sg}$ & sg & 5.0 & 0.6 & 0.7 \\
\hline W6 2558 & $\mathrm{sg}$ & $\mathrm{sg}$ & 4.5 & & \\
\hline W6 1890 & $\mathrm{sg}$ & wk & 4.4 & & \\
\hline PI 540362 & $\mathrm{sg}$ & wk & 3.9 & 1.3 & 2.7 \\
\hline PI 515972 & $\mathrm{sg}$ & wk & 3.5 & & \\
\hline W6 1861 & $\mathrm{sg}$ & $\mathrm{sg}$ & 2.9 & 0.8 & $\mathrm{nf}$ \\
\hline PI 540349 & $\mathrm{sg}$ & wk & 1.8 & 1.0 & $\mathrm{nf}$ \\
\hline W6 12825 & $\mathrm{sg}$ & sg & 1.5 & 0.1 & $\mathrm{nf}$ \\
\hline PI 540346 & $\mathrm{sg}$ & wk & 0.0 & & \\
\hline PI 540360 & $\mathrm{sg}$ & sg & 0.0 & & \\
\hline W6 1862 & $\mathrm{sg}$ & wk & 0.0 & & \\
\hline W6 1883 & $\mathrm{sg}$ & wk & 0.0 & & \\
\hline W6 4462 & wk & wk & 0.0 & & \\
\hline W6 10738 & $\mathrm{sg}$ & $\mathrm{sg}$ & 0.0 & & \\
\hline W6 12820 & $\mathrm{sg}$ & sg & 0.0 & & \\
\hline W6 17260 & wk and ns & wk & 0.0 & & \\
\hline PI 250662 & sg & ns & & & \\
\hline PI 470923 & $\mathrm{sg}$ & harv & & & \\
\hline PI 493105 & $\mathrm{sg}$ & harv & & & \\
\hline PI 497951 & $\mathrm{sg}$ & harv & & & \\
\hline PI 540315 & wk and ns & harv & & & \\
\hline PI 540318 & sg & harv & & & \\
\hline PI 540321 & wk and ns & harv & & & \\
\hline PI 540328 & wk and ns & harv & & & \\
\hline PI 540371 & wk and ns & harv & & & \\
\hline PI 543049 & sg & harv & & & \\
\hline W6 670 & wk and ns & harv & & & \\
\hline W6 1860 & wk and ns & harv & & & \\
\hline W6 2560 & wk and ns & ns & & & \\
\hline W6 4464 & wk and ns & harv & & & \\
\hline W610472 & sg & harv & & & \\
\hline W6 10473 & sg & harv & & & \\
\hline W6 10734 & wk and ns & harv & & & \\
\hline W6 10739 & wk and ns & harv & & & \\
\hline W6 12911 & sg & harv & & & \\
\hline W6 17281 & wk and ns & harv & & & \\
\hline
\end{tabular}

${ }^{2} \mathrm{sg}=$ Strong, $\mathrm{wk}=$ weak, $\mathrm{ns}=$ nonstalking (no scape), harv $=$ harvested before flower stalk (scape) development was completed, $\mathrm{nf}=$ no flowers developed. accessions the development of bulbils in the place of ovaries and styles (epigynous flowers), the growth of a second whorl of flowers growing from the primary flowers, or the presence of bulbils without flowers was observed. Splitting of mature flower receptacles was observed among umbels with $>200$ flowers. In split umbels, typical garlic flowers shed pollen, but the whole inflorescence wilted very quickly. The number of plants with flowering anomalies varied between clones, and was highest in PI 540349 and W6 12825. As expected, the number of seeds harvested from plants with umbel anomalies was very low (1.8 and 1.5 seeds/stalk, respectively for PI 540349 and W6 12825).

Of 36 accessions with a strong stem base in bulbs used as the planting material, 19 dein bulbs used as the planting material, 19 de-

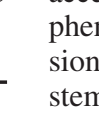

\section{s.} sion. The most stable traits, such as flower stem appearance, opening ability of spathe in early stages of flower development, the level of difficulty to remove bulbils, tepal color, umbel shape and the number of flowers per umbel, were similar across the populations evaluated. The position of stigma, the closure of tepals, pollen shed, pollen viability, time of flowering, length of filaments, scape senescence rate, and number of seeds produced by individual plants (data not shown) varied more between plants within an accession. The WRPIS garlic collection is a valuable source of selection material for developing true seed fertile garlic.

To date, the most significant technique applied to improve garlic production has been in vitro virus free plant production. To a limited extent, some garlic improvement has been realized by selection of clonal material or the selection of somaclonal variants. In the future, however, seed fertile clones and sexual reproduction can provide a base for development of new phenotypes by syngamy and recombination. After breeding and selection, new phenotypes may be either propagated vegetatively or from true seed. Important benefits from true seed in garlic may include their novelty, reduction of virus titer (Walkey et al., 1987), and nematodes, the two most serious pests in garlic clove seed at the present time. The development of true seeded garlic cultivars may enable garlic cultivation using practices common for onion and leek, but production from true seed may not be widely used commercially until high bulb yielding seed cultivars are developed.

\section{Literature Cited}

Etoh,E. 1983. Accomplishments of microsporogensis in a garlic clone. Mem. Fac. Agr. Kogoshima Univ. 5(19):55-63.

Etoh, E. 1986. Fertility of garlic clones collected in Soviet Central Asia. J. Jpn. Soc. Hort. Sci. 55(3):312-319.

Etoh, T., Y. Noma, Y. Nishitarumizu, and T. Wakamoto. 1988. Seed productivity and germinability of various garlic clones collected in Soviet Central Asia. Mem. Fac. Agric, Kogoshima University. 24(33):129-139.

Harris, J.G. and M. Woolf Harris. 1994. Plant identification terminology. An illustrated glossary. Spring Lake Publ., Utah. 
Table 3. Scape, umbel and flowering characteristics of seed producing garlic accessions.

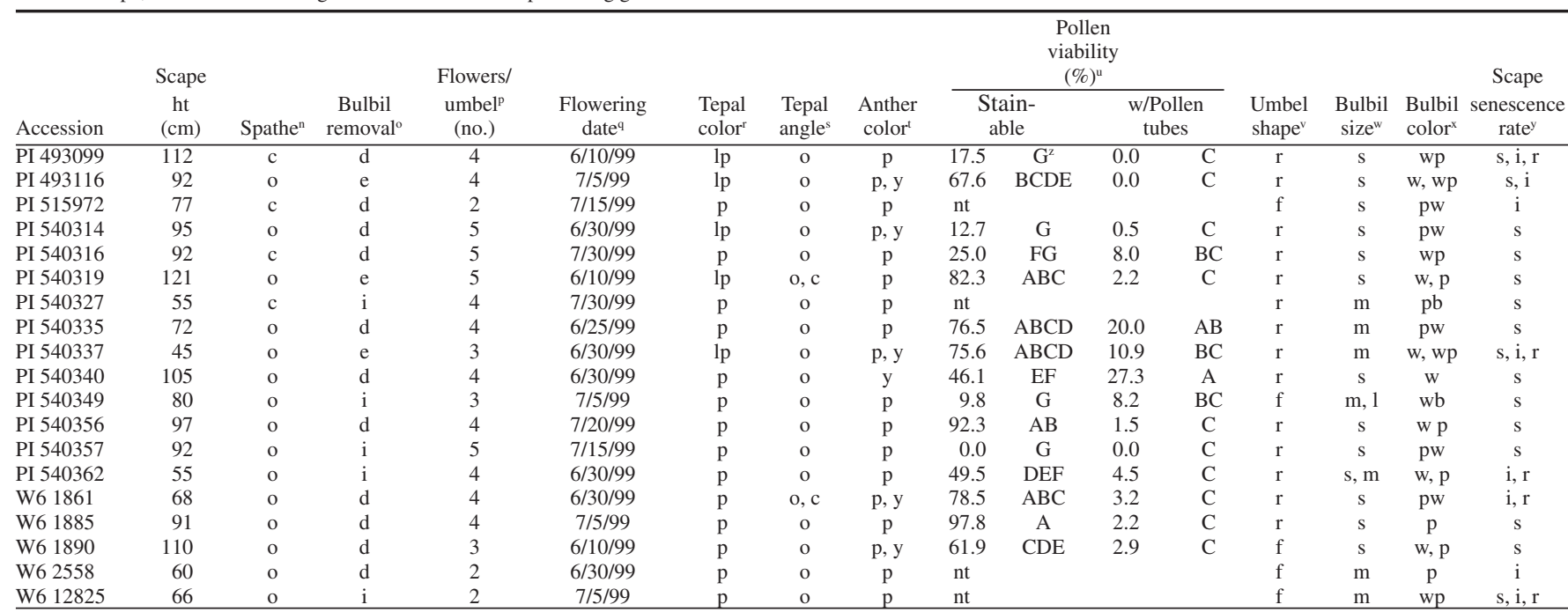

"Spathe: $\mathrm{c}=$ closed, $\mathrm{o}=$ open naturally.

${ }^{\circ}$ Bulbil removal: $\mathrm{d}=$ difficult, $\mathrm{e}=$ easy, $\mathrm{i}=$ intermediate.

PFlower number/umbel ranking: $1=\leq 10,2=11$ to $50,3=51$ to $100,4=101$ to $200,5=>200$

${ }^{q}$ Flowering date: beginning of flowering when 10 flowers were opened on $1 / 3$ of umbels.

'Tepal color: $\mathrm{lp}=$ light purple, $\mathrm{p}=$ purple.

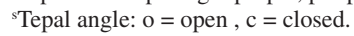

Anther color: $\mathrm{p}=$ purple, $\mathrm{y}=$ yellow.

Pollen germination rate: $\mathrm{nt}=$ not tested.

"Umbel shape: $f=$ flat, $r=$ round

"Bulbil size: $\mathrm{s}=$ small, $\mathrm{m}=$ medium, $1=$ large.

Bulbil color: $\mathrm{p}=$ purple, $\mathrm{pb}=$ purple brown, $\mathrm{pw}=$ purple white, $\mathrm{w}=$ white

'Scape senescence rate: $\mathrm{s}=$ slow, $\mathrm{i}=$ intermediate, $\mathrm{r}=$ rapid.

${ }^{2}$ Mean separation, LSD, $P \leq 0.01$.

Hua, Q.Y., H. Takagi, N. Nobuyoshi, and T. Etoh 1994. Development of types of inflorescences of garlic and some Allium species. J. Jpn. Soc. Hort. Sci. 63(1):121-130.

Inaba, A., T. Ujiie, and T. Etoh. 1995. Seed productivity and germinability of garlic (in Japanese) Breed. Sci. 45 (Suppl. 2):310.

Jenderek, M.M. 1998. Generatywne rozmanazanie czosnku (Allium sativum L.) (in Polish) [(Generative propagation of garlic (Allium sativum L.)] Zeszyty Naukowe Akademii Rolniczej im. H. Kollataja w Krakowie. 333:141-145.

Jenderek, M.M. and R.M. Hannan. 2000. Seed producing ability of garlic (Allium sativum L.) clones from two U.S. public collections. Proc. 3rd Intl. Symp. Edible Alliaceae. Athens, Ga (Nov.)3:73-75.

Kamenetsky, R. and H. D. Rabinowitch. 2001. Floral development in bolting garlic. Sex. Plant Reprod. 13:325-241.

Kazakova,A.A. 1971. Most common onion species, their origin and intraspecific classification (in Russian). Trudy po prikladnoi Botanike, genetike I Selektsii 45:19-41.

Kononkow, P.F. 1953. The question of obtaining garlic seed (in Russian). Sad i Ogorod 8:38-40.

Konvicka, O. 1984. Generative reproduction of garlic (Allium sativum) (in German). Allium Nwslt. 1:1-17.

Mann, L.K. 1952. Anatomy of the garlic bulb and factors affecting bulb development. Hidgardia 21(8):195-251.

Mann, L.K. 1958. Growth and bulbing of garlic (Allium sativum L.) in response to storage temperature of planting stocks, day length, and planting date. Hildgardia 27(15):384-419.

Mann, L.K. 1957. Growing garlic in California. Univ. Calif. Veg. Crops Ser. 89:1-10.

Mann, L.K., T.M. Little, and W.L. Sims. 1961 Growing garlic in California. Univ. Calif. Agr. Ext. Serv. AXT-28:1-13.

Pooler, M.R and P.W. Simon. 1993. Garlic flower- ing in response to clone, photoperiod, growth temperature, and cold storage. HortScience 28(11):1085-1086

Pooler, M.R. and P.W. Simon. 1994. True seed production in garlic. Sex. Plant Reprod. 7(5):282-286.

Simon, P.W. and M.M. Jenderek. 2003. Flowering, seed production and the genesis of garlic breeding. Plant Breed. Rev. 23:211-244.

SPPS Inc. 2001. SPSS for windows release 10.1. Chicago, Ill.

Takagi, H. 1990. Garlic Allium sativum L, p.109-146. In: J.L. Brewster and H.D. Rabinowitch (eds.). Onion and allied crops. vol. 3. Biochemistry, food science, and minor crops. CRC Press. Boca Raton, Fla.

Walkey, D.G.A., M.J.W. Weeb, C.J. Bolland, and A. Miller.1987. Production of virus-free garlic (Allium sativum L.) and shallot (A. ascalonicum L.) by meristem-tip culture. J. Hort. Sci.62:211-220. 